\title{
PUBLIC-PRIVATE-PEOPLE PARTNERSHIP AS A WAY TO REDUCE CARBON DIOXIDE EMISSIONS FROM RESIDENTIAL DEVELOPMENT
}

\author{
Matti KURONEN ${ }^{1}$, Seppo JUNNILA ${ }^{2}$, Wisa MAJAMAA ${ }^{3}$ and Ilkka NIIRANEN 4 \\ ${ }^{1}$ Real Estate Research Group, School of Science and Technology, Aalto University, \\ P.O. Box 11200, 00076 Aalto, Finland \\ E-mail: matti.kuronen@tkk.fi \\ 2 Real Estate Research Group, School of Science and Technology, Aalto University, \\ P.O. Box 11200, 00076 Aalto, Finland \\ 3 ICECAPITAL Real Asset Management, Ltd., Finland \\ ${ }^{4}$ Fortum, Ltd., Finland
}

Received 27 October 2009; accepted 14 May 2010

\begin{abstract}
This paper examines the possibility of Public-Private-People partnership (4P) model as a way to reduce carbon dioxide emissions from residential developments. The case project focuses on the energy system design as a part of urban planning. Based on the case experiences, the paper presents a $4 \mathrm{P}$ framework for low-carbon residential development systems. The theoretical model was tested in one specific case project, Nupurinkartano. The major findings were that the $4 \mathrm{P}$ framework is a relevant tool for decreasing carbon emissions when planning a new development; the applied solution delivered an energy system design that could reduce the $\mathrm{CO}_{2}$ emissions of the development by $75 \%$. Based on literature this paper suggests that a new development should be viewed as one system instead of several different subsystems. The paper concludes by suggesting that $4 \mathrm{P}$ offers an alternative approach for urban planning, specifically energy system planning, and it can deliver significant improvements in carbon efficiency.
\end{abstract}

KEYWORDS: New residential developments; Energy system planning; Public-Private-People partnership (4P); Carbon dioxide emissions

\section{INTRODUCTION}

Cities grow worldwide, both within their juridical borders and as commuter sheds of several independent municipalities. Kennedy et al. (2007) defined the situation where no single entity defines the rules for urban growth by term "commuter shed". Behind urban growth, there are urban planning processes that weigh different aspects of planning, such as house type, housing volume, traffic system, infrastructure, services, and many more, and create new residential developments. However, traditionally neither of the previous growing patterns considers urban planning process as a single system but as several, often linear, non-related sub-systems and processes, which typically include strong barriers between the responsibilities of the public and private sectors and between municipalities and inhabitants (Healey, 1998; Väyrynen, 2007).

One way of examining a residential development as a system is to study its inputs and outputs, metabolism. Ayres (1994) introduced the idea of metabolism in this context. It refers 
to energy and material flows in ecological communities. In this approach, the planning concentrates on the flows of the functional system, what it takes from outside its geographical borders, and what it returns back. For example, infrastructure services are systems that typically are operated from a remote plant, consumed in the area, with emissions again handled elsewhere. This view of regarding a system as inputs and outputs has often been used in industrial ecology (IE), ever since Ayres (1994), White (1994), and Frosch (1992) defined it. Energy systems are heterogeneous, they contain different levels and are distributed but can be studied by means of integrated assessment (IA) (Agusdinata and DeLaurentis, 2008).

Climate change mitigation and reduction of carbon emissions has a high prominence in the European Union (EU). Accordingly, the carbon influence of the housing sector has been studied vigorously. For example, Norman et al. (2006) have emphasized the significance of housing in Canada. Other studies by Bin and Dowlatabadi (2005), Munksgaard et al. (2000), Reinders et al. (2003), and Lenzen (1998) have highlighted household energy use and related greenhouse gas (GHG) emissions as the most significant indicator of environmental pressure. Household heating is estimated to represent 10 percent of the total GHG emissions in both the EU- $15^{1}$ and the EU- $27^{2}$ countries (European Environmental Agency, 2008).

1 EU-15 refers to Austria, Belgium, Denmark, Finland, France, Germany, Greece, Ireland, Italy, Luxembourg, the Netherlands, Portugal, Spain, Sweden and the United Kingdom.

2 EU-27 refers to EU-15 plus Bulgaria, Cyprus, the Czech Republic, Estonia, Hungary, Latvia, Lithuania, Malta, Poland, Slovakia, Slovenia and Romania, which all joined the Union in either 2004 or 2007.
In northern parts of the continent, heating energy plays an even greater role in GHG emissions. In Finland, for example, household heating has a share of 21 percent (Tilastokeskus, 2008). A Europe-wide comparison has been conducted by Bürger et al. (2008), who claim that it will not be possible to meet the requirements of climate targets without increasing the use of renewable energies in heating. Due to the high influence of energy in the housing sector, there is an urgent call for a low-carbon solution for heating and cooling services.

New regulations have also been presented regarding energy efficiency and renewable energy in newbuilt houses. These include the European Commission's EU 2020 objectives (European Commission, 2005), which aim at having a higher proportion of renewable energy being used. The European Commission (2005) and other studies (Moll et al., 2005; Simola et al., 2007) have estimated that in Europe, about 40 percent of national energy use and GHG emissions are related to household services consisting of heating, production of domestic hot water and cooling.

The purpose of this study is to examine the possibility of achieving measurable results in reducing carbon emissions with a PublicPrivate-People partnership (4P) approach for planning low-carbon residential developments and offering an alternative path for energy system design for them. Bringing fourth $\mathrm{P}$, people, to the field of planning adds complexity to formerly sequential system. This study is based on two propositions: First, that the traditional urban planning process does not effectively meet the carbon challenge of residential development; and second, that the new residential development could be viewed as a system in order to reduce the carbon emissions.

The paper uses the Public-Private-People partnership (4P) framework in urban planning and brings the future inhabitants to residential 
development system. A new 4P framework for an urban planning process is presented, and further, applied to the planning of a holistic energy system for a new housing development in northern Europe. The study restricts its scope to the energy system (energy production, heating, and cooling) of the residential development.

The paper is structured so that we first present a theoretical $4 \mathrm{P}$ framework for residential developments and residential developments as systems; then the framework is applied to a case project; and finally, the improved framework is suggested. The Case study compares two alternative scenarios for providing heating services for the new residential development. The first is business as usual and the second is the 4P-based. Finally, the overall findings relevant to the research propositions are presented and conclusions are drawn.

\section{RESEARCH DESIGN AND METHODS}

\subsection{Research design}

Research is carried out by first creating a theoretical framework of $4 \mathrm{P}$ based urban development system. Secondly, a case study is conducted where the theoretical framework is tested. And finally, an improved theoretical framework for residential development as a 4P-based system is presented. Flyvjberg (2006) underlines the need for studying cases that are not too common in order to be at the forefront of a scientific discipline. In addition, Allenby (2006) encourages this type of research in order to deal with complexities that are not found in nature.

A case-study approach has been adopted here. The new residential development project area of Nupurinkartano in Espoo in southern Finland is the case. The project's decisionmaking process during the energy system design was the main focus of observation. Nupu- rinkartano was selected as the case area for following reasons:

- The area had no existing energy system and was thus open for new solutions;

- The land was privately owned and the private developer also had an active role in the urban planning phase of the project; and

- The area was allocated for housing in the general plan.

Nupurinkartano was analyzed from the beginning of the urban planning project in 2005 until the approval of the detailed plan in 2009 through documents and reports produced in the planning process and the active role of the researchers themselves in the process. The active role of researchers in fact-finding for practical problem-solving in social situations can be used to improve the related quality of action (Patton, 1990; Burns, 1997). Due to this, the researchers have had an important role in the development process for the case area.

The Nupurinkartano planning process has been studied before. The focus of the studies was on customer participation and participatory planning (Staffans et al., 2009; Majamaa et al., 2008a). This study builds on the results of these previous studies and examination of the planning process and planning documents from the beginning of the urban planning project in 2005 until the approval of the detailed plan in 2009. These include the final detailed plan and plan description and proposal versions of them, formal opinions received, a more detailed level block plan, infrastructure plans and conducted surveys.

\subsection{Theory: New residential developments, systems and $4 \mathrm{P}$}

The theoretical background of this study is related to public-private partnerships in urban planning. The urban planning framework in this study is the 4P model (Public-Private-People Partnership), an application of PPP (Public- 
Private Partnership), as defined by Majamaa et al. (2008b) and Majamaa (2008). In the 4P model, there are three primary actors in urban planning: the municipality (Public), the developer (Private), and the end-users (People).

Real life phenomena, like urban planning, require not only observation and research, but informed decisions and technology solutions as well (Allenby, 2006; Ehrenfeld, 2004; Korhonen, 2004). Contemporary problems are normative, whereas science is always suggested to be positive by nature (Ehrenfeld, 2007; Allenby, 1999). This also matches Ehrenfeld's (2007) "the normative imperative of sustainability" in planning.

These basic assumptions form also the launching pad for IA, an approach to provide relevant and usable information to decisionmaking of complex issues (Van Asselt and Rothmans, 2002). It has been successfully used in describing energy systems by e.g. Agusdinata and DeLaurentis (2008).

\section{New developments viewed as systems}

The residential development system mixes elements of political, economic, and social decision-making with technically oriented industrial processes and urban planning. As we cannot just specify it geographically, it is more functional to approach its elements by system boundaries. Also Van Asselt and Rothmans (2002) underline this legitimation of system boundaries. Allenby (2006) and Lahti et al. (2006) distinguish system boundaries from geographical boundaries defined by political decisions, whereas Amin $(2002,67)$ clearly states that "Infrastructures are complex networks, geographically dispersed, nonlinear, and interacting both among themselves and with their human owners, operators and users". Ehrenfeld (2007) goes one step further, claiming that the modernist paradigm includes geo-political boundaries, whereas the sustainability paradigm has natural boundaries. This distinction is also widely admitted in the planning theories (Van Assche and Verschraegen, 2008). Herein, urban planning is understood in its inclusive form as a way in which a community affects its members' quality of life, environment, social and economic infrastructure, and not just actual plan-making (Friedmann, 2005; Lemmetty et al., 2005). Residential development as a system consists of a limited amount of actors (households) and a supply system designed for them.

Urban planning very much defines the energy system design later in the process, because system definitions are made during the urban planning phase and boundaries are formed by political decisions before the actual planning (Lahti et al., 2006). Still, urban planning is treated as planning that considers only the spatial characteristics of a certain area. Modernist planning aims at creating one 'right' solution by analyzing area qualities. However, geographical and biological surveys do not cover qualities such as the potential for producing energy locally. Korhonen (2004) emphasizes the need for inter-organizational focus, which often gets lost in the traditional urban planning process. Collaborative urban planning is about governing networks and partnerships (Agger and Löfgren, 2008).

We study the flow of energy in consumer activity and its carbon emissions in order to pursue the design of an energy productionconsumption system. In residential development both thermal efficiency of dwellings and used heating technology are vital as is energy infrastructure and consumption patterns (Agusdinata and DeLaurentis, 2008). New development needs both ecosphere (nature and its elements) and technosphere (man-made environment) around it in order to get water, heat, and electricity. Emissions caused by the technosphere, such as GHG's and sewage, end up in the ecosphere. The environmental system generates all the flows and receives all the waste and emissions (Allenby, 2006). Here the 
new residential development acts as a major source of interaction between human (urban planning) and natural (metabolism) systems.

The residential development system overlaps with the environmental system, because it consists not only of houses, roads, and technical infrastructure, but also of the living environment and nature support system needed by inhabitants. When new homes are built in a new development, it gives us a chance to view the development as a holistic eco- and technosystem with its inputs and outputs.

\section{P framework for new developments}

One important point of view in the decisionmaking process in a new residential development is the end-users. Urban planning in Europe and elsewhere has been strongly connected to rationality and power. There have traditionally been two main players: local government and the developer (Majamaa, 2008; Mäntysalo, 2002; Flyvjberg, 1998). In Finland, developer usually has a significant role in developing private-owned land (Lahdenperä, 2009; Majamaa, 2008). Recently a third actor, people, has been introduced (Majamaa et al., 2008b; Lemmetty et al., 2005). Here, "people" refers to the end users of the system, that is, the residents of the residential development.

Currently, people cannot affect system planning but are obliged to join the formed monopolies in energy and water supply (Majamaa et al., 2008a). Both interfaces, municipality-developer and developer-end user are unilateral, with information and decision-making going only downstream, and discontinuities do occur (Väyrynen, 2007). Actors and their roles in the urban planning process by Väyrynen (2007) and Majamaa (2008) are presented in Table 1.

The end users, people, are these consumers that we are bringing to our framework, as well.

\section{CASE STUDY}

\subsection{Nupurinkartano new development and its planning process}

The Nupurinkartano residential development is a greenfield area located in the municipality of Espoo and will consist of single-family, duplex, and row houses. It will be home to over 500 people. Permitted housing volume is about 28,000 square meters. Besides housing, there is only an inferior amount of about $300 \mathrm{sqm}$ of permitted commercial building volume.

Land is privately owned so both the private owner and the developer have an active role in the planning process. End users and potential end users have been actively involved in the planning process of the area and have participated in the urban planning. Former reports (Staffans et al., 2009; Majamaa et al., 2008a) clearly show the desire of citizen-consumers for more sustainable new developments and different planning methods and opportunity to participate when comparing $4 \mathrm{P}$ and traditional urban planning.

Table 1. Actors and their roles in the urban planning process

\begin{tabular}{llll}
\hline Actor & Public (Municipality) & Private (Developer) & People (End users) \\
\hline \multirow{2}{*}{ Role } & - defines urban planning and & - develops area and brings & - end users of system \\
& infrastructure systems & new ideas to markets & - use energy \\
& - controls the input flows & - delivers the project & - produce waste and generate \\
& (energy, water) & - defines technical systems & emissions \\
& for buildings &
\end{tabular}

Source: Väyrynen (2007); Majamaa (2008) 
In none of the planning documents mentioned in chapter 2.1 or discussions the energy system planning played any significant role. The only point it was mentioned was in the plan proposal phase, where the opinion of energy operator was asked about energy service on the area similarly when opinions of e.g. phone networks or wastewater networks were asked from their operators.

\subsection{Traditional and 4P-based urban planning processes}

In the traditional situation, the developer does have only little decision-making power within the planning process as a whole. Decisions are made top down: the municipality at the top makes the important decisions affecting system level and these decisions are handed down to the developer to implement and to deal with the consequences of them. At the very bottom is the end user. So neither the end user nor the developer have the opportunity to contribute to the top-level planning decisions. The traditional process is said to be sequential and information gets lost in it (Väyrynen, 2007). The traditional urban planning process is led by the public sector, typically the municipality. It provides regulations concerning the planning, draws the plans itself, and sometimes even delivers the energy system. In the traditional process the private party, the developer, delivers the houses and their technical systems according to public sector decisions. The top-down system constrains those downstream, the developer and end user, that is. In this case, the developer tends to be investment cost-oriented and ends up choosing the option with the lowest investment cost.

People, existing and future inhabitants, are only end users of the system and have no opportunity to affect the decisions concerning the energy system design. Relationships between public and private as well as private and people are unilateral, the latter acting based on decisions made by the former. People, final users of the new development, customers of the developer and citizens of the municipality, are only involved as citizens with a possibility of leaving their comments at a certain phase in the detailed plan approval process. The only form of feedback in the traditional planning process is formal comments from people to public authority.

The traditional preference for heating systems in urban areas of Finland is district heating produced in combined heat and power (CHP) plants and delivered by a local energy operator, where available. This is a clear outcome from the planning process in Nupurinkartano as well, where local planning authorities asked only the opinion of private energy operator owning district heating network in Espoo. In the planning phase, the local energy operator stated that the Nupurinkartano area is too far from the district heating network, so the developer had to actively search for other alternatives. The usual form of a heating system would in this case be direct electric heating, due to its low investment costs and ease of delivery (Energiateollisuus, 2008a). This is a clear example of restrictions going downstream.

The Public-Private-People based process (4P) originates from Majamaa's (2008) observation that direct customer contact is missing from PPP-based urban planning process on a general level.

The 4P-based process is interactive and includes direct formal and informal relations between all P's, not only formal participation. Public-Private relations are part of typical PPP urban planning, where the private sector has an active role in plan-making and financing projects. As part of the Public-Private relations, the public party works together with the developer, 
who also supplies private resources to the municipality and shares the costs of planning. The private sector is responsible for the actual planning material and background studies related to planning (Majamaa, 2008). Thus PPP can also be viewed as part of $4 \mathrm{P}$. In the case study the Private initiated the $4 \mathrm{P}$ together with the researchers in order to get more knowledge about future inhabitants' wishes.

The role of participation and local decisionmaking can be characterized as formal PublicPeople relations. The most interesting part of the $4 \mathrm{P}$ process is the interface between the private sector and the people - the potential end-users of the new development. This can be characterized as Private-People relations. The interface between Private and People
(Private-People relations) is a novel approach in urban planning in Finland. Usually this relationship only occurs in the marketing and sales phase, after the planning has long been completed.

Figure 1 presents both traditional and $4 \mathrm{P}$ urban planning processes. The traditional process is sequential, so the previous actor defines the starting point, and thus the possibilities for its follower. In energy system designing, this means that the public party (municipality) makes decisions about the system, the developer chooses property level heating technology according to that, and the people have no choice left. The $4 \mathrm{P}$ process is interactive with direct relations between all the actors in the planning phase.

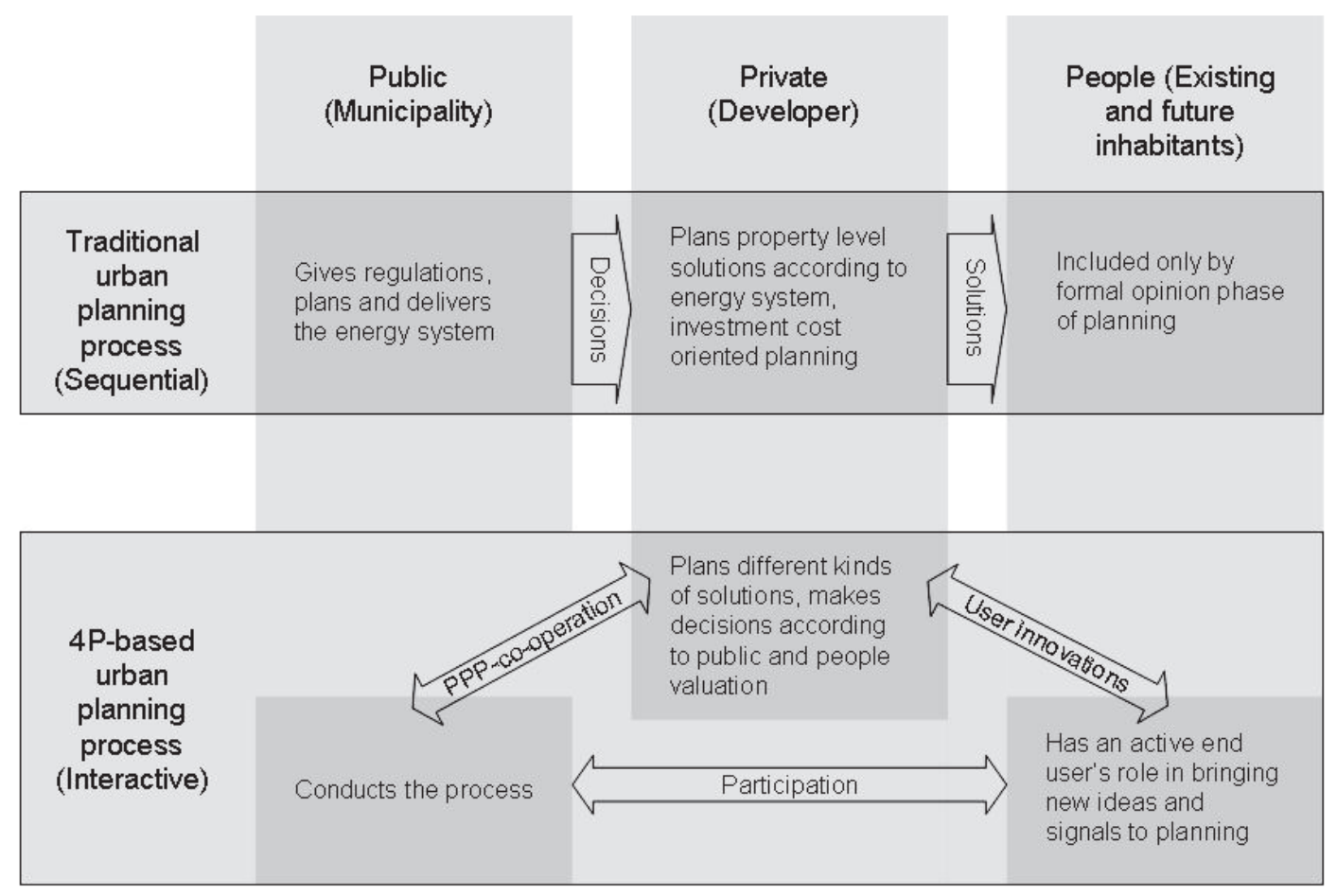

Figure 1. Traditional and $4 \mathrm{P}$ urban planning process, where PPP is viewed as Public-Private relationship of $4 \mathrm{P}$.

The roles of the actors and interfaces between them in residential development energy system planning and urban planning 


\subsection{Urban planning and energy system design process in Nupurinkartano}

In the $4 \mathrm{P}$-based urban planning process applied in Nupurinkartano, the public conducted the planning by political decisions. The municipality, the developer, and the landowners outsourced the actual plan-making to consultants. This can be characterized as Public-Private relations.

One of the informal yet effective participation methods used for Private-People relations -- an open, unstructured, two-phase internet questionnaire -- was a completely new participation method in urban planning processes in Finland. Other methods were meetings held between people, private and public authorities, environmental groups and civil society organizations, and an internet forum (Majamaa, 2008). Authors participated in arranging informal participation mentioned here alongside with formal planning process.

The $4 \mathrm{P}$ process, especially the questionnaire, clearly brought out the future inhabitants' wishes for more sustainable housing (Majamaa, 2008; Staffans et al., 2009) that again led to a discussion of energy system design because its crucial role in emissions. Also, due to the inaccessibility of traditional district heating mentioned in the plan, a new energy solution was needed. The energy system design was conducted in workshops led by the developer in which the authors also participated. After several workshops and meetings between the developer, the energy operator, and the heating system provider, an alliance was formed in order to develop a sustainable energy system to deliver energy to housing in Nupurinkartano. Different possibilities were investigated during 2007. It is worth noticing that energy issues are not mentioned in the official detailed plan report or mandatory environmental impact assessment report but private and people stakeholders brought the issue to the planning.
A common understanding strengthened by the $4 \mathrm{P}$ process was that direct electric heating is too unsustainable a solution to survive in the consumer market in the long run. The developer did not want property-specific heating systems because of the obligation to maintain them for ten years after selling the property. A local closed-loop system using renewable energy and measurable improvements for the whole development was thus a common goal. An emission-cutting oriented, economically feasible energy system design approach was then selected and system boundaries were set by energy system requirements and not by the planning process.

At first, only options with property-specific solutions were examined. The most promising technology available from a low GHG emissions point of view was a ground heat system. Then a wider scope was selected and a decision was made to commit to research an areal ground heat system. The conceptual technology testing for the system was done by the Helsinki University of Technology and the Geological Survey of Finland. It was found that rock in Nupurinkartano is suitable for heat production and that technical systems for buildings can be designed to use a low heat resource (Foda et al., 2008; Leppäharju et al., 2008). Furthermore, it was found that adding ground cooling improves the system efficiency even more as presented in section 4. All property level solutions and centralized ground heat solution proposed in the workshops were simulated in order to get comparable quantitative data.

The formal planning process and the $4 \mathrm{P}$ advanced simultaneously in Nupurinkartano as presented below in Figure 2. Majamaa (2008) and Staffans et al. (2009) have already reported effects of $4 \mathrm{P}$ to detailed plan that enables customer to have more options in house planning phase. Also the municipality planning authorities found information gathered via $4 \mathrm{P}$ very useful and gave chance for new kind of methods. 


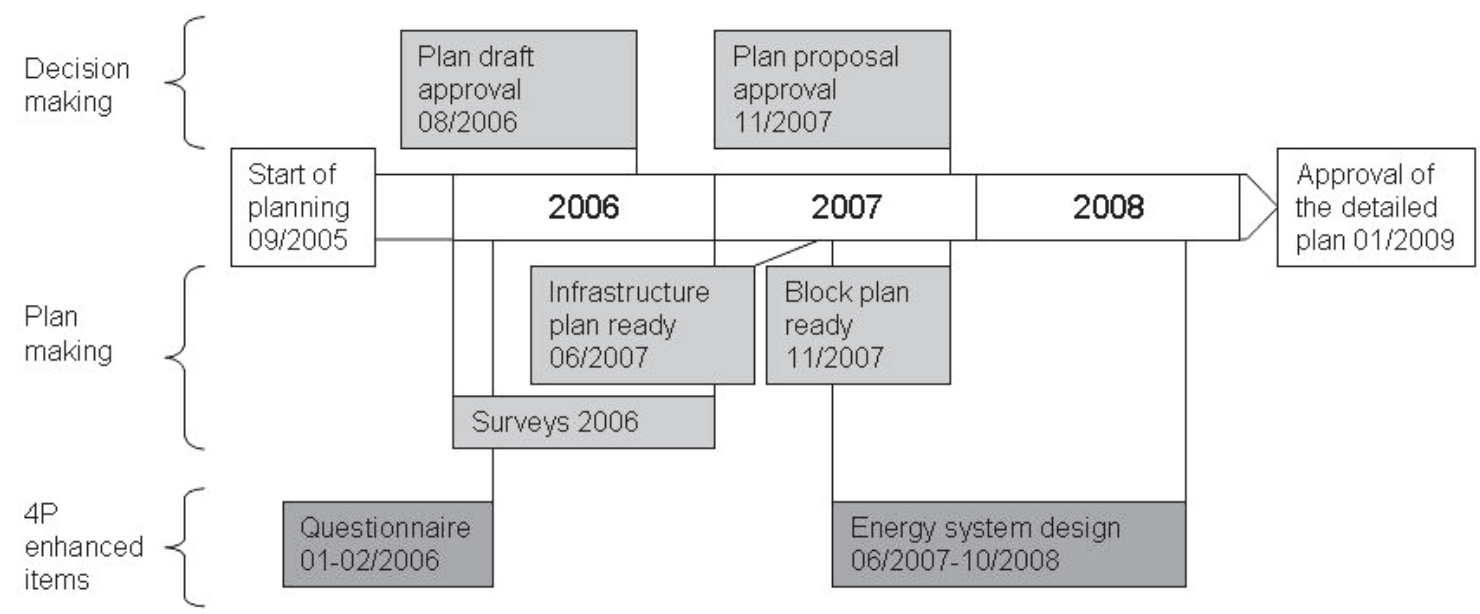

Figure 2. Timeline of formal decision making and $4 \mathrm{P}$ planning process in Nupurinkartano

In Nupurinkartano, development roles and interfaces were clearly 4P-based. The lack of energy issues in the formal plan fuelled the emergence of the $4 \mathrm{P}$ process. The private party actively sought solutions for providing an energy infrastructure and encouraged the involvement of people in the planning. Thus, a renewable heating and cooling energy system could be designed for the area. Additionally, the developer-end user interface was bilateral, a result of the $4 \mathrm{P}$ approach. During the research, an economically sustainable solution to deliver the system was developed.

\section{RESULTS AND FINDINGS}

\subsection{The case-specific energy use and carbon emission simulations}

The simulations were calculated separately for each optional property-specific heating system as well as for the centralized ground heat system. $\mathrm{CO}_{2}$ emission calculations of electricity production have been done using the average of Nordic electricity pool production and coal condensate electricity (Tilastokeskus, 2005; Flyktman and Helynen, 2004; IPCC, 2001;
Energiateollisuus, 2008b). The carbon calculations contain only the $\mathrm{CO}_{2}$ emissions from the actual energy production process without earlier life-cycle phases of the energy systems. The starting values of carbon emission simulations are presented in Tables $2-5$.

Table 2. $\mathrm{CO}_{2}$ emission factors for different fuels

\begin{tabular}{ll}
\hline Fuel & $\mathrm{CO}_{2}$ emission factor $\left[\mathrm{t} \mathrm{CO}_{2} / \mathrm{TJ}\right]$ \\
\hline Coal & 94.6 \\
Light fuel oil & $74 ., 1$ \\
Natural gas & 56.1 \\
\hline
\end{tabular}

Source: Tilastokeskus (2005)

Table 3. $\mathrm{CO}_{2}$ emission factors by electricity production types

\begin{tabular}{ll}
\hline Electricity production type & $\begin{array}{l}\mathrm{CO}_{2} \text { emission factor } \\
{\left[\mathrm{g} \mathrm{CO}_{2} / \mathrm{kWh}\right]}\end{array}$ \\
\hline $\begin{array}{l}\text { Coal condensate (efficiency in } \\
\text { electricity production 43\%) }\end{array}$ & 792 \\
$\begin{array}{l}\text { Wind, water } \\
\begin{array}{l}\text { Nordic-mix (Nordic electricity } \\
\text { pool average) }\end{array}\end{array}$ & 0 \\
\hline
\end{tabular}

Source: IPCC (2001); Flyktman and Helynen (2004); Energiateollisuus (2008b) 
Table 4. Heating $\mathrm{CO}_{2}$ emission factors

\begin{tabular}{|c|c|c|c|}
\hline Heating type & $\begin{array}{l}\text { Efficiency in heat } \\
\text { production }\end{array}$ & Fuel & $\begin{array}{l}\mathrm{CO}_{2} \text { emission factor } \\
{\left[\mathrm{g} \mathrm{CO}_{2} / \mathrm{kWh}\right]}\end{array}$ \\
\hline Property specific oil heating & $90 \%$ & Light fuel oil & 296.4 \\
\hline Property specific natural gas heating & $95 \%$ & Natural gas & 212.6 \\
\hline Property specific direct electric heating & $100 \%$ & Nordic-mix & 98.0 \\
\hline Property specific direct electric heating & $100 \%$ & Coal condensate & 792.0 \\
\hline Property specific direct electric heating & $100 \%$ & $\begin{array}{l}\text { Natural gas combi } \\
\text { (condensate) }\end{array}$ & 367.2 \\
\hline Property specific ground heat pump & $300 \%$ & Nordic-mix & 32.7 \\
\hline Property specific ground heat pump & $300 \%$ & Coal condensate & 264.0 \\
\hline Property specific ground heat pump & $300 \%$ & $\begin{array}{l}\text { Natural gas combi } \\
\text { (condensate) }\end{array}$ & 122.4 \\
\hline Centralized area ground heat system & $400 \%$ & Nordic-mix & 24.5 \\
\hline Centralized area ground heat system & $400 \%$ & Coal condensate & 198.0 \\
\hline Centralized area ground heat system & $400 \%$ & $\begin{array}{l}\text { Natural gas combi } \\
\text { (condensate) }\end{array}$ & 91.8 \\
\hline
\end{tabular}

Source: IPCC (2001); Flyktman and Helynen (2004)

Table 5. Energy use in Nupurinkartano

\begin{tabular}{lll}
\hline Nupurinkartano energy use (domestic hot water) & 1,240 & MWh/a \\
\hline Nupurinkartano energy use (Heating) (as per 2001 weather data) & 1,493 & MWh/a \\
Total & 2,733 & MWh/a \\
\hline
\end{tabular}

Source: Foda et al. (2008)

The results of the calculations showing the $\mathrm{CO}_{2}$ emissions caused by heating and domestic hot water production in all of Nupurinkartano are presented in Figures 3 and 4. The areal ground heat system is the only studied system where the energy for cooling is also included in the energy consumption and $\mathrm{CO}_{2}$ calculations.

When comparing the yearly $\mathrm{CO}_{2}$ emissions of the heating system of the whole development, it becomes evident that direct electric heating or oil heating are clearly inferior compared to the areal ground heat solution in $\mathrm{Nu}$ purinkartano. Emission calculations are based on energy consumption values calculated by Foda et al. (2008) using IDA Indoor Climate and Energy 3.0 software and Earth Energy Design software. Foda et al. (2008) show that energy consumption (heating, cooling, and domestic hot water) in the area would be 97.4 kWh/sqm/year, thus achieving Finnish energy class A based on the EU directive concerning building energy efficiency (European Union, 2002).

Compared to direct electric heating, the areal ground heat system is superior in $\mathrm{CO}_{2}$ emissions. Emissions were calculated here with the estimation that the yearly efficiency of the property-specific ground heat system is the typical 300\% (meaning that one unit of electricity used in heat pumps produces three units of heat), while the efficiency of the centralized areal ground heat system is $400 \%$. According to Leppäharju et al. (2008), the final results for the areal system could even be better than that. 
The centralized system is superior to a property-specific one because it allows two compressors to be used in series while still remaining economically feasible (Foda et al., 2008).

The sensitivity of the carbon calculation was also tested with the coal condensate elec- tricity, which has the largest $\mathrm{CO}_{2}$ footprint of all available power production methods. Even in the case of coal condensate electricity used in the heat pumps, the areal ground heat system is the best alternative regarding $\mathrm{CO}_{2}$ emissions, as can be seen in Figure 3.

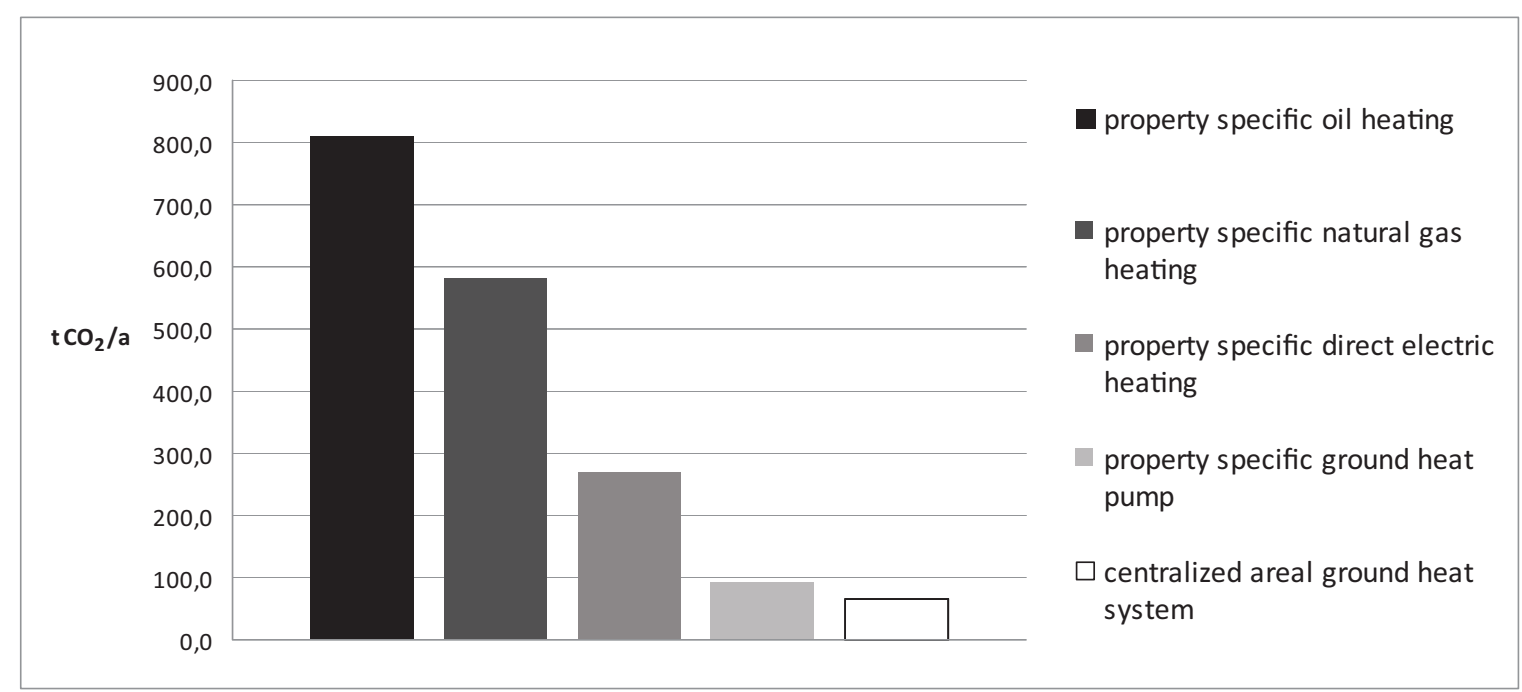

Figure 3. Yearly $\mathrm{CO}_{2}$ emissions in Nupurinkartano when Nordic mix electricity is used to power the heat pumps

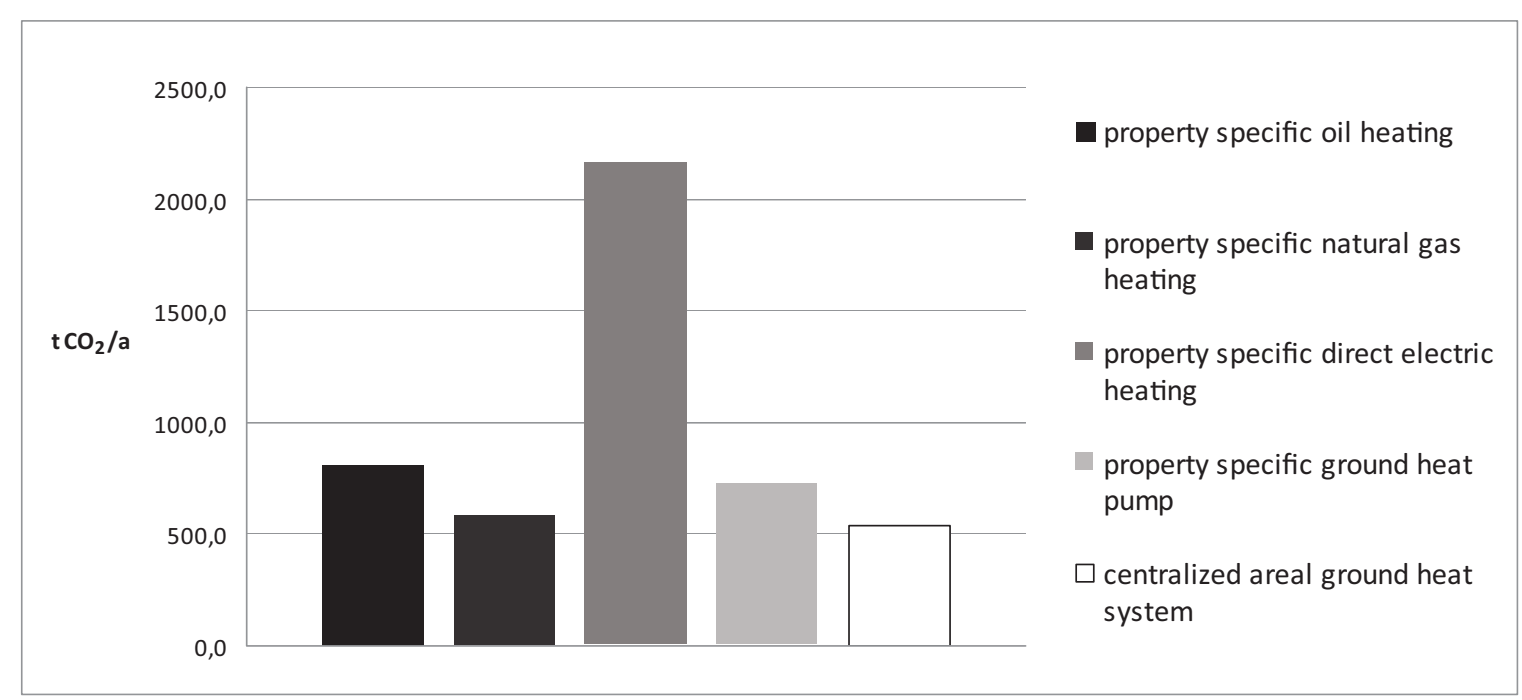

Figure 4. Yearly $\mathrm{CO}_{2}$ emissions in Nupurinkartano when coal condensate electricity is used to power the heat pumps 
In the Nupurinkartano case, the centralized areal ground heat system was the best of the simulated options. The relative carbon benefits of the centralized areal ground heat system depend on the production technology of electricity, but in all cases it provided the lowest level of $\mathrm{CO}_{2}$ emissions. In addition, the centralized areal ground heat system adds value for the consumer because it includes cooling.

In summary, the environmental benefits of using the centralized areal ground heat system are the following:

- The new system provides $75 \%$ lower $\mathrm{CO}_{2}$ emissions than the business-as-usual scenario;

- Even in the worst-case scenario, where coal condensate electricity is used, the ground heat system is better than heating by oil or gas; and

- Only one-fourth the electricity is used compared to direct electric heating, so $\mathrm{CO}_{2}$ emissions are only one-fourth regardless of the way in which the electricity is produced.

\subsection{The usability of $4 \mathrm{P}$ framework in reducing carbon emissions}

Based on the case Nupurinkartano experiences, $4 \mathrm{P}$ can be a successful way to conduct emission oriented urban planning. Areal ground heat was selected as energy system. The local environment is included in the system because heat is produced locally. The whole urban planning process is entwined with the possibility to produce energy locally for the whole area. It is a closed-loop system with only a small amount of external energy flow representing about one-fourth of the energy produced. The advantages of ground heat are stable production even during the wintertime, a low level of $\mathrm{CO}_{2}$ emissions, no need for a separate plant, and independence of municipal heating networks, reliable technology, and possibility of cooling. The investments in boreholes, the most expensive part of the system, can be done synchronously as residential quarters are built. For inhabitants, the system is as easy to use as traditional district heating would be. The results of energy system planning were not part of final detailed plan approved in 2009 but plan regulations were formed so that areal ground heat system could be located in the area.

The new development is viewed as one system including the local environment instead of several different subsystems or overlapping systems. Inputs and outputs are viewed on a system level, and emphasis is put on local alternatives like local energy production in $\mathrm{Nu}$ purinkartano. There are direct relationships between consumers, people, and producers; in the case presented, there are relationships between final energy consumers and the designers of the production system. $4 \mathrm{P}$ planning process of a new development helped to achieve measurable results in the case. Urban planning is actually seen as a process of controlling flows within the "system" under development, whereas traditional urban planning is a sequential planning project having no throughpassing flows involved.

\section{DISCUSSION}

The purpose of this study is to examine the possibilities of achieving measurable results in reducing carbon emissions with a Public-PrivatePeople partnership (4P) approach for planning low-carbon residential developments and offering an alternative path for energy system design for them. Bringing fourth P, people, to the field of planning adds complexity to system.

This research had two aims. The first was to test whether the $4 \mathrm{P}$ framework can lead to decreasing in carbon dioxide emissions of residential developments. The second was to consider whether the people be presented as part of the residential development system instead of being just the tail of present sequential and fragmented process. 
The technical result of the study was that the tested 4P framework for the energy system design for a residential development led to a clear decrease in $\mathrm{CO}_{2}$ emissions when compared with the business-as-usual scenario. This was also emphasized by the potential new inhabitants in previous stages of the $4 \mathrm{P}$ process. The decrease in carbon emissions was already hypothesised at the beginning of the study, but the magnitude of the reduction (fourfold) was still a surprise. A more conceptual result of the study was that the residential development system is improved, albeit with increased complexity, by adding $4^{\text {th }} \mathrm{P}$.

The originality and value of this paper lie in providing a new way of thinking for urban planners, policy makers, and developers. The design of the energy system for Nupurinkartano was the first recorded instance in the research literature of $4 \mathrm{P}$ being used as a planning method for the energy system design of a new development.

No previous studies were found that would combine the $4 \mathrm{P}$ and reducing $\mathrm{CO}_{2}$ emissions. However, some European studies exist where system level thinking and redistribution of responsibilities has led to improvements. A classical example is the Kalundborg eco-industrial park in Denmark. Ehrenfeld and Gertler (1997) have claimed that the key to success at Kalundborg was a sequence of independent, economically driven actions, but the evolutionary pattern found may not be easily transferable to greenfield developments. In this study, Nupurinkartano is a greenfield development, but the solution was introduced via economically driven actions. A study of Dutch rental apartments presented that private decision makers can significantly contribute to governmental environmental policies by improving the energy performance of their existing housing stock (Smid and Nieboer, 2008). In Nupurinkartano developer made similar strategic decisions than professional landlords in the Dutch study. Baas and Boons (2004) investigated Rotterdam harbor as an IE system. They found out that long-term growth and sustainable development combined with IE in the harbor region requires for new institutional arrangements. In Nupurinkartano, $4 \mathrm{P}$ can be viewed as such an institutional arrangement. Björklund et al. (1999) studied one subsystem of urban development, waste management. They stated that generation of energy is crucial in sustainable waste management. In the Stockholm case, material is turned into energy, whereas in the Nupurinkartano case, the existing local energy resource (latent ground heat) is utilized. In a study carried out in Sweden, Mahapatra and Gustavsson (2008) have noticed similar reductions in emissions as those found in the $\mathrm{Nu}$ purinkartano case in the ground heat system. They also emphasise that using ground heat is economically feasible.

The reduction in carbon emissions can mostly be explained by a significant systemlevel change in the energy system design and the widening of the system itself from property-specific to an areal system and from heating only to heating that includes cooling. Technically, the better carbon efficiency compared to the property-specific solution was achieved by a centralized solution allowing several heat pumps to be used and put in series. Also, the possibility of cooling and thus charging the rock in summertime improves the efficiency and adds value to the system. In a traditional urban planning process, the developer lacks decision-making capabilities concerning the whole planning process. The strategic management of the whole development process is much more complicated. End-users have little or no effect on their emissions and all participants feel compelled simply to choose the system that costs least. In a 4P framework, the active management of the whole process is possible.

This case study presented one $4 \mathrm{P}$-based residential development. Based on a single case, it cannot be assumed that the same results would be achieved in all new residential 
developments. Planning cultures, legislation, and market situation differ country by country. $4 \mathrm{P}$ is not the only way to end up with an areal ground heat solution, nor does the solution require $4 \mathrm{P}$-based residential development even if we suggested that traditional urban planning process would have led another path in this case. In traditional public authority-led planning, the solution is possible but requires the Public to act differently.

There is also a question of the role of researchers as both detached scientific observers and participant actors. We had to be able to assume responsibility and to commit personally to the information we had partly produced and the questions we have promoted or opposed with the help of that information. We have no reason to suppose that the results are unreliable. We also have made our participant status clear. On the other hand, the combining of research and practical work has also made it possible to introduce new real-life questions into this research.

The $4 \mathrm{P}$ framework proved to stand up to closer examination in reducing carbon dioxide emissions in one case study in the Finnish market, climate, and planning system. The areal ground heat solution presented in the study could be used elsewhere, and, the applied technology is widely available. Similarly, fairly similar external conditions can be expected to exist in new residential development projects, both in Finland and elsewhere at northern latitudes. When district heating is not available, it pays off to aim for a centralized areal solution instead of property level systems. The results may offer a fruitful alternative approach for the process in cases with similar conditions.

On a conceptual level, it seems suitable to couple a 4P framework for a residential development with the design of an energy system. However, more studies are needed for further generalizations. Further research is also needed to couple other parts of planning to the framework, such as design of other subsystems of new development (e.g., water and sewage systems, transportation systems). Similarly, a life-cycle assessment (LCA) would be needed for a more comprehensive study of the energy system. An organization-level LCA concerning the development project is thus possible only by viewing the whole energy system ( $\mathrm{Ny}$ et al., 2006). Finally, it would also be worth researching the roles of all the actors and interdependence between them; that is, to further study PPP and 4P in urban development and the role of public authorities. Integrated assessment could well be used in this kind of study.

This kind of $4 \mathrm{P}$ urban planning suggests a variety of other possibilities for the future. The results of this article should be of value to developers, planning authorities, and politicians, locally and nationally. Other sustainability indicators should be included in the framework in order to create a broader framework for sustainable urban development.

\section{CONCLUSIONS}

This study rested on two propositions: First, that the traditional urban planning process does not effectively meet the carbon challenge of residential development; and second, that the new residential development could be viewed as a system in order to reduce the carbon emissions. The study showed that both of the suggested propositions are true in the case of residential energy systems development.

The conclusion of this case study is that $4 \mathrm{P}$ is a suitable framework for the energy system design of a new residential development and that it offers significant measurable improvements for urban planning. It also became clear that in the case of Nupurinkartano, the energy system planning could be fruitfully coupled with aims to reduce carbon emissions.

By examining one specific case we have suggested that following the path of IE in urban planning will help achieve results in decreasing carbon emissions. In the study, clear 
differences between the $4 \mathrm{P}$ framework and the traditional urban planning process were identified, one of those being the design of the energy system; and the other, the interaction between the developer and the end-users. Based on the results, no silver bullet could be found for achieving more sustainable new developments, but the $4 \mathrm{P}$ framework offers a promising approach to decrease the carbon emissions of residential developments.

\section{ACKNOWLEDGMENT}

This article was supported financially by Maa- ja Vesitekniikan tuki ry (Finnish Association for Support of Civil Engineering). Geological and technical studies carried out by Helsinki University of Technology and the Geological Survey of Finland were partially financed by Tekes. Dr. Chris Heywood from University of Melbourne has provided some very valuable comments for this article.

\section{REFERENCES}

Agger, A. and Löfgren, K. (2008) Democratic assessment of collaborative planning processes, Planning Theory, 7(2), pp. 145-164. doi:10.1177/1473095208090432

Agusdinata, D. B. and DeLaurentis, D. (2008) Specification of system-of-systems for policymaking in the energy sector, The Integrated Assessment Journal, 8(2), pp. 1-24.

Allenby, B. R. (1999) Industrial ecology: policy framework and implementation. Prentice-Hall, Inc.

Allenby, B. R. (2006) The ontologies of industrial ecology? Progress in Industrial Ecology, An International Journal, 3(1-2), pp. 28-40.

Amin, M. (2002) Toward secure and resilient interdependent infrastructures, Journal of Infrastructure Systems, 8(3), pp. 67-75. doi:10.1061/(ASCE)1076-0342(2002)8:3(67)

Ayres, R. U. (1994) Industrial metabolism: theory and policy. In: Industrial metabolism, edited by R. U. Ayres and U. E. Simonis. Tokyo: United Nations University Press.
Baas, L. W. and Boons, F. A. (2004) An industrial ecology project in practice: exploring the boundaries of decision-making levels in regional industrial systems, Journal of Cleaner Production, 12(8-10), pp. 1073-1085. doi:10.1016/j.jclepro.2004.02.005

Bin, S. and Dowlatabadi, H. (2005) Consumer lifestyle approach to US energy use and the related $\mathrm{CO}_{2}$ emissions, Energy Policy, 33(2), pp. 197-208. doi:10.1016/S0301-4215(03)00210-6

Björklund, A., Bjuggren, C., Dalemo, M. and Solesson, U. (1999) Planning biodegradable waste management in Stockholm, Journal of Industrial Ecology, 3(4), pp. 43-58. doi:10.1162/108819899569683

Burns, R. (1997) Introduction to Research Methods, Longman, $3^{\text {rd }}$ edition, Melbourne, Australia.

Bürger, V., Klinski S., Lehr, U., Leprich, U., Nast, M. and Ragwitz, M. (2008) Policies to support renewable energies in the heat market, Energy Policy, 36(8), pp. 3150-3159. doi:10.1016/j.enpol.2008.04.018

Ehrenfeld, J. and Gertler, N. (1997) Industrial ecology in practice: the evolution of interdependence at Kalundborg, Journal of Industrial Ecology, 1(1), pp. 67-79. doi:10.1162/jiec.1997.1.1.67

Ehrenfeld, J. (2007) Would industrial ecology exist without sustainability in the background? Journal of Industrial Ecology, 11(1), pp. 73-84. doi:10.1162/jiec.2007.1177

Ehrenfeld, J. R. (2004) Can industrial ecology be the "Science of sustainability"? Journal of Industrial Ecology, 8(1-2), pp. 1-3. doi:10.1162/1088198041269364

Energiateollisuus (2008a) Kunnat päättävät myös energiasta [Finnish Energy Industry, Municipalities make decisions about energy, brochure]. (In Finnish)

Energiateollisuus (2008b) Sähkön alkuperän ilmoittaminen asiakkaalle. Muistio [Telling electricity source to customer. Memo]. Available at: http://www.energia.fi/fi/sahko/sahkokauppa/ sahkonalkuperanilmoittaminenasiakkaalle/ labelling-suositus\%2030-6-08.pdf (In Finnish)

European Commission (2005) COM/2005/0265 Green Paper on Energy Efficiency.

European Environmental Agency (2008) Greenhouse gas emission trends and projections in Europe 2008. 
European Union (2002) Directive 2002/91/EC of the European Parliament and of the Council of 16 December 2002 on the energy performance of buildings.

Flyvjberg, B. (1998) Rationality and power: democracy in practice, University of Chicago Press, Chicago, IL.

Flyvjberg, B. (2006) Five misunderstandings about case-study research, Qualitative Inquiry, 12(2), pp. 219-245. doi:10.1177/1077800405284363

Flyktman, M. and Helynen, S. (2004) Hyötysuhteiden määrittäminen päästökaupan alkujakoa varten [Defining efficiencies for emission trade] VTT Tutkimusselostus PRO2/0071T/03. Available at: http://www.tem.fi/files/13627/HyOtysuhteiden_mAArittAminen_pAAstOkaupan_ alkujakoa_varten.pdf (In Finnish)

Foda, E., Hasan, A. and Siren, K. (2008) Draft planning of Nupuri area building energy supply and end-use systems. Unpublished company report. Helsinki University of Technology.

Friedmann, J. (2005) Globalization and the emerging culture of planning, Progress in Planning, 64(3), pp. 183-234.

doi:10.1016/j.progress.2005.05.001

Frosch, R. A. (1992) Industrial ecology: a philosophical introduction, Proceedings of the National Academy of Sciences of the United States of America, 89(3), pp. 800-803. doi:10.1073/pnas.89.3.800

Healey, P. (1998) Collaborative planning in a stakeholder society, Town Planning Review, 69(1), pp. 1-21.

IPCC (2001) Climate change 2001: Working group III: Mitigation. Appendix IV. Available at: http://www.ipcc.ch/ipccreports/tar/wg3/477. htm

Kennedy, C., Cuddihy, J. and Engel-Yan, J. (2007) The changing metabolism of cities, Journal of Industrial Ecology, 11(2), pp. 43-59. doi:10.1162/jie.2007.1107

Korhonen, J. (2004) Theory of industrial ecology, Progress in Industrial Ecology, An International Journal, 1(1/2/3), pp. 61-88.

Lahdenperä, P. (2009) Phased multi-target areal development competitions: algorithms for competitor allocation, International Journal of Strategic Property Management, 13(1), pp. 1-22. doi:10.3846/1648-715X.2009.13.1-22

Lahti, P., Calderón, E., Jones, P., Rijsberman, M. and Stuip, J. (eds.) (2006) Towards sustainable urban infrastructure: assessment, tools and practice. European Science Foundation.

Lemmetty, M., Väyrynen, E., Rantanen, H., Staffans, A. and Smeds, R. (2005) Urban planning and everyday life: a learning process. Article at IFIP workshop June 5th-7th 2005. In: Smeds, R. et al. Experimental Interactive Learning in Industrial Management: New approaches to Learning, Studying and Teaching, Helsinki University of Technology.

Lenzen, M. (1998) Primary energy and greenhouse gases embodied in Australian final consumption: an input-output analysis, Energy Policy, 26(6), pp. 495-506. doi:10.1016/S0301-4215(98)00012-3

Leppäharju, N., Engström, J., Kallio, J., Nordbäck, N. and Tiensuu, K. (2008) Geoenergy study on Nupurinkartano area. Unpublished company report. Helsinki University of Technology.

Mahapatra, P. and Gustavsson, L. (2008) Innovative approaches to domestic heating: homeowners' perceptions and factors influencing their choice of heating system, International Journal of Consumer Studies, 32(1), pp. 75-87.

Majamaa, W., Kuronen, M., Kostiainen, J. and Heywood, C. (2008a) A new customer-orientated participation method for communicative planning, International Journal of Housing Markets and Analysis, 1(1), pp. 68-80. doi:10.1108/17538270810861166

Majamaa, W., Junnila, S., Doloi, H. and Niemistö, E. (2008b) End-user oriented Public-Private Partnerships in real estate industry, International Journal of Strategic Property Management, 12(1), pp. 1-17. doi:10.3846/1648-715X.2008.12.1-17

Majamaa, W. (2008) The 4th P - People - in Urban Development Based on Public-Private-People Partnership. TKK Structural Engineering and Building Technology Dissertations, 2 TKK-RVK2. Helsinki University of Technology.

Moll, H. C., Noorman, K. J., Kok, R., Engström, R., Throne-Holst, H. and Clark, C. (2005) Pursuing more sustainable consumption by analyzing household metabolism in European countries and cities, Journal of Industrial Ecology, 9(1-2), pp. 259-275. doi:10.1162/1088198054084662

Munksgaard, J., Pedersen, K. A. and Wien, M. (2000) Impact of household consumption on $\mathrm{CO}_{2}$ emissions, Energy Economics, 22(4), pp. 423-440. doi:10.1016/S0140-9883(99)00033-X 
Mäntysalo, R. (2002) Dilemmas in critical planning theory, Town Planning Review, 73(4), pp. 417436. doi:10.3828/tpr.73.4.3

Norman, J., MacLean, H. L. and Kennedy, C. A. (2006) Comparing high and low residential density: life-cycle analysis of energy use and greenhouse gas emissions, Journal of Urban Planning and Development-ASCE, 132(1), pp. 10-21. doi:10.1061/(ASCE)0733-9488(2006)132:1(10)

Ny, H., MacDonald, J. P., Broman, G., Yamamoto, R. and Robèrt, K. (2006) Sustainability constraints as system boundaries. An approach to making life-cycle management strategic, Journal of Industrial Ecology, 10(1-2), pp. 61-77. doi:10.1162/108819806775545349

Patton, M. (1990) Qualitative evaluation and research methods. Sage, London.

Reinders, A. H. M. E., Vringer, K. and Blok, K. (2003) The direct and indirect energy requirements of households in the European Union, Energy Policy, 31(2), pp. 139-153. doi:10.1016/S0301-4215(02)00019-8

Simola, K., Sipilä, O., Kivi-Koskinen, H. and Ilvonen J. (2007) Energian tuotanto ja käyttö: Pohjaselvitys uuden ohjelman selvitysvaihetta varten. Sitra [Energy production and use. Base study of new program]. (In Finnish)

Smid, J.-W. and Nieboer, N. (2008) Energy-efficient asset management for professional landlords, International Journal of Strategic Property Management, 12(1), pp. 19-34. doi:10.3846/1648-715X.2008.12.19-34
Staffans, A., Väyrynen, E., Huisko, S. and Melama, S. (2009) Kumppanuus. In: Staffans, A. and Väyrynen, E. (eds.) 2009. Oppiva kaupunkisuunnittelu. Teknillinen korkeakoulu, arkkitehtuurin laitoksen julkaisuja 2009/98 [Partnership]. (In Finnish)

Tilastokeskus (2005) Polttoaineluokitus [Fuel classification]. Available at: http://www.stat.fi/tup/ khkinv/polttoaineluokitus.html

Tilastokeskus (2008) Energiatilasto [Energy statistics]. Available at: http://tilastokeskus.fi/til/ ene_en.html

Van Assche, K. and Verschraegen, G. (2008) The limits of planning: Niklas Luhmann's systems theory and the analysis of planning and planning ambitions, Planning Theory, 7(3), pp. 263-283. doi:10.1177/1473095208094824

Van Asselt, M. B. A. and Rothmans, J. (2002) Uncertainty in integrated assessment modelling, Climatic Change, 54(1-2), pp. 75-105. doi:10.1023/A:1015783803445

Väyrynen, E. (2007) Planning and implementation from separation to joint processes. Nordic Planning Research Symposium on Local Authority Planning in Change: Beyond Dichotomies, August 16-18, 2007, Oulu. University of Oulu, Department of Architecture.

White, R. M. (1994) Preface. In: The greening of industrial ecosystems, edited by Allenby, B. R. and Richards, D. J. Washington, DC: National Academy Press.

\section{SANTRAUKA}

\section{VIEŠOJO IR PRIVATAUS SEKTORIŲ BEI ŽMONIŲ PARTNERYSTE் KAIP BŪDAS MAŽINTI ANGLIES DVIDEGINIO EMISIJAS GYVENAMUOSIUOSE RAJONUOSE}

\section{Matti KURONEN, Seppo JUNNILA, Wisa MAJAMAA, Ilkka NIIRANEN}

Šiame darbe nagrinejjama galimybè viešojo ir privataus sektorių bei žmoniu partnerystès (angl. Public-Private-People Partnership - 4P) modelį taikyti kaip būdą mažinti anglies dvideginio emisijas gyvenamuosiuose rajonuose. Pasirinktame projekte daugiausia demesio skiriama energetikos sistemos projektavimui, kuris yra miestų planavimo dalis. Remiantis atvejo patirtimi, darbe pristatoma 4P struktūra, skirta mažai anglies dvideginio išmetančioms gyvenamuju rajonų sistemoms. Teorinis modelis išmėgintas pasirinkus konkretu projektą Nupurinkartano rajone. Padaryta išvada, kad, planuojant naują rajona, 4P struktūra - tinkama priemonè mažinti anglies dvideginio emisijas. Pritaikius šį sprendimą buvo parengtas energetikos sistemos projektas, $\mathrm{CO}_{2}$ emisijas rajone galintis sumažinti 75 proc. Remiantis literatūros šaltiniais šiame darbe teigiama, kad nauja rajoną reikètu traktuoti kaip vieną sistema, o ne kelis skirtingus posistemius. Darbas baigiamas teigiant, kad $4 \mathrm{P}$ - tai alternatyvus miestu, ypač energetikos sistemų, planavimo būdas, galintis suteikti galimybių veiksmingai mažinti anglies dvideginio emisijas. 